\title{
Chemogenetic Suppression of GnRH Neurons during Pubertal Development Can Alter Adult GnRH Neuron Firing Rate and Reproductive Parameters in Female Mice
}

\author{
${ }^{\circ}$ Eden A. Dulka, ${ }^{1}{ }^{-}$R. Anthony DeFazio, ${ }^{1}$ and ${ }^{-S}$ Suzanne M. Moenter ${ }^{1,2,3}$
}

https://doi.org/10.1523/ENEURO.0223-20.2020

${ }^{1}$ Department of Molecular and Integrative Physiology, University of Michigan, Ann Arbor, MI 48109, ${ }^{2}$ Department of Internal Medicine, University of Michigan, Ann Arbor, MI 48109, and ${ }^{3}$ Department of Obstetrics and Gynecology, University of Michigan, Ann Arbor, MI 48109

\begin{abstract}
Gonadotropin-releasing hormone $(\mathrm{GnRH})$ neurons control anterior pituitary, and thereby gonadal, function. $\mathrm{GnRH}$ neurons are active before outward indicators of puberty appear. Prenatal androgen (PNA) exposure mimics reproductive dysfunction of the common fertility disorder polycystic ovary syndrome (PCOS) and reduces prepubertal GnRH neuron activity. Early neuron activity can play a critical role in establishing circuitry and adult function. We tested the hypothesis that changing prepubertal $\mathrm{GnRH}$ neuron activity programs adult $\mathrm{GnRH}$ neuron activity and reproduction independent of androgen exposure in female mice. Activating (3Dq) or inhibitory (4Di) designer receptors exclusively activated by designer drugs (DREADDs) were targeted to $\mathrm{GnRH}$ neurons using Cre-lox technology. In control studies, the DREADD ligand clozapine n-oxide (CNO) produced the expected changes in $\mathrm{GnRH}$ neuron activity in vitro and luteinizing hormone (LH) release in vivo. CNO was administered to control or PNA mice between two and three weeks of age, when GnRH neuron firing rate is reduced in PNA mice. In controls, reducing prepubertal $\mathrm{GnRH}$ neuron activity with 4Di increased adult $\mathrm{GnRH}$ neuron firing rate and days in diestrus but did not change puberty onset or GABA transmission to these cells. In contrast, activating $\mathrm{GnRH}$ neurons had no effect on reproductive parameters or firing rate and did not rescue reproductive phenotypes in PNA mice. These studies support the hypothesis that prepubertal neuronal activity sculpts elements of the adult reproductive neuroendocrine axis and cyclicity but indicate that other PNA-induced programming actions are required for full reproductive phenotypes and/or that compensatory mechanisms overcome activity-mediated changes to mitigate reproductive changes in adults.
\end{abstract}

Key words: chemogenetic; development; infertility; neural activity; neuroendocrine

\section{Significance Statement}

Gonadotropin-releasing hormone $(\mathrm{GnRH})$ neuron activity and associated $\mathrm{GnRH}$ release link the neuronal control of reproduction to peripheral secretion of reproductive hormones. Prenatally androgenized (PNA) mice mimic neuroendocrine aspects of polycystic ovary syndrome (PCOS). PNA reduces prepubertal GnRH neuron activity but increases adult activity. Here, we reveal that prepubertal suppression of GnRH neuron activity without androgen exposure leads to similar increases in adult $\mathrm{GnRH}$ neuron activity, and a mild degradation in reproductive cycles. Increasing GnRH neuron activity before puberty, however, fails to rescue cycles in PNA mice. This provides a clearer understanding of the role prepubertal GnRH neuron activity plays in establishing adult reproductive function and suggests additional androgen-dependent programming actions are required for complete reproductive disruption in this model and perhaps PCOS. 


\section{Introduction}

Reproduction is required for the perpetuation of individual species and is controlled through the hypothalamicpituitary-gonadal axis. Gonadotropin-releasing hormone $(\mathrm{GnRH})$ neurons are the final central neuronal output of this axis; they release $\mathrm{GnRH}$ from terminals in the median eminence to regulate luteinizing hormone (LH) and follicle-stimulating hormone (FSH) synthesis and secretion by the anterior pituitary. $\mathrm{LH}$ and $\mathrm{FSH}$ activate gonadal functions, including steroidogenesis. Gonadal-steroid feedback regulates hormone release at both the level of the brain and the pituitary. Disruptions in this axis can lead to infertility, which is estimated to affect up to one in six couples (Hartman et al., 2006; Thoma et al., 2013). The leading cause of infertility in women of childbearing age is polycystic ovary syndrome (PCOS; McCartney et al., 2002). Hyperandrogenemic PCOS affects $8-10 \%$ of women and is characterized by oligo/anovulation, mildly elevated androgens, and persistent high frequency of $\mathrm{LH}$, and presumably $\mathrm{GnRH}$, release (Livadas et al., 2014). Most studies of PCOS have occurred in adults, a time when reduced fertility is easily noted and diagnosis based on established criteria is possible. Increasing evidence, however, suggests aspects of PCOS emerge before and/ or during the pubertal transition (McCartney et al., 2007; Burt Solorzano et al., 2010; Collins et al., 2014).

To study mechanistic underpinnings of PCOS at a neuronal level, animal models are needed. Prenatal androgenization (PNA) recapitulates many aspects of PCOS in several species including rodents, primates and sheep (Abbott et al., 1998; Foecking et al., 2005; Padmanabhan and Veiga-Lopez, 2013). Recent studies in mice demonstrated GnRH neurons are active and receive synaptic inputs well before outward signs of reproduction are present (Dulka and Moenter, 2017; Berg et al., 2018). PNA treatment altered both $\mathrm{GnRH}$ neuron firing rate (Roland and Moenter, 2011; Dulka and Moenter, 2017) and GABA transmission to these cells before puberty, as well as in adulthood (Sullivan and Moenter, 2004; Berg et al., 2018). Early neuronal activity in other areas of the brain contributes to organization of neuronal networks by attracting and pruning synaptic inputs (Katz and Shatz, 1996; Andreae and Burrone, 2014), but the role of prepubertal

Received May 26, 2020; accepted May 28, 2020; First published June 8, 2020. The authors declare no competing financial interests.

Author contributions: E.A.D. and S.M.M. designed research; E.A.D. and R.A.D. performed research; E.A.D. and R.A.D. analyzed data; E.A.D., R.A.D., and S.M.M. wrote the paper.

This work was supported by the National Institutes of Health/Eunice Kennedy Shriver National Institute of Child Health and Human Development Grant P50 HD28934 (to S.M.M.) and a National Science Foundation Graduate Research Program Fellowship.

Acknowledgements: We thank Laura Burger and Elizabeth Wagenmaker for expert technical support and the latter for valuable editorial comments.

Correspondence should be addressed to Suzanne M. Moenter at smoenter@umich.edu

https://doi.org/10.1523/ENEURO.0223-20.2020

Copyright @ 2020 Dulka et al.

This is an open-access article distributed under the terms of the Creative Commons Attribution 4.0 International license, which permits unrestricted use, distribution and reproduction in any medium provided that the original work is properly attributed.
GnRH neuron activity with regard to the reproductive neuroendocrine system is not known.

The above correlational studies pose interesting questions regarding possible programming roles of PNA exposure versus changes that occur subsequent to PNAinduced alterations in neuronal activity. Specifically, PNA treatment reduces $\mathrm{GnRH}$ neuron activity relative to controls before puberty (Dulka and Moenter, 2017). Is it androgen exposure that leads to increased GnRH neuron activity and increased excitatory (DeFazio et al., 2002) GABAergic input in adult PNA mice, or can changing prepubertal GnRH neuron activity alone produce or rescue the reproductive phenotype? We hypothesized that decreasing GnRH neuron activity during the prepubertal period in control mice would lead to similar phenotypes observed in PNA mice including increased GnRH neuron activity and GABAergic inputs to these cells in adulthood. We also hypothesized that activating these cells before puberty in PNA mice would rescue adult reproduction. To test these postulates, we used a chemogenetic approach to modify $\mathrm{GnRH}$ neuron activity before puberty, and subsequently monitor adult neurophysiology and reproductive parameters.

\section{Materials and Methods}

All chemicals were acquired from Sigma-Aldrich unless noted.

\section{Animals}

Transgenic mice (C57Bl6/J) expressing Cre recombinase (Cre) under the $\mathrm{GnRH}$ promoter in a BAC construct (GnRH-Cre mice, JAX 021207; Yoon et al., 2005) were crossed onto mice expressing green fluorescent protein (GFP) under control of the GnRH promoter [ $\mathrm{Tg}(\mathrm{GnRH} 1$ EGFP)51Sumo MGl:6158457, GnRH-GFP mice, JAX 033639; Suter et al., 2000] until homozygous for both GFP and Cre (GnRH-GFP/Cre mice). Homozygous GnRH-Cre and $\mathrm{GnRH}$-GFP/Cre mice were then crossed to mice expressing a floxed cassette encoding one of two versions of a designer receptor exclusively activated by designer drugs (DREADD), mCitrine and the hemagglutinin (HA) tag (Fig. $1 A$ ). In these mice, when Cre is present, a floxed stop cassette is removed and the CAG promoter drives expression of the cassette. The DREADDs used in these studies were hM3Dq (3Dq, JAX, 026220) and hM4Di (4Di, JAX, 026219), which activate the canonical $\mathrm{Gq}$ and $\mathrm{Gi}$ pathways, respectively. These receptors are activated by the DREADD ligand clozapine n-oxide (CNO) or its metabolite, clozapine (Gomez et al., 2017). Table 1 shows the mouse genotypes used for the experiments presented in the following studies and the abbreviations used for these in the text. All mice used in this study were heterozygous for $\mathrm{GnRH}$-Cre, GnRH-GFP and CAG-DREADD (hM3Dq or hM4Di), unless noted.

Because this study focused on the PNA phenotype as a model for PCOS in women, these studies only used female mice. Adult females (estrous cycles were monitored from 9 to 12 weeks of age and again two weeks before electrophysiological recordings performed at 18-43 weeks of age). All ovary-intact mice used for experiments were in the diestrous cycle stage verified via vaginal cytology. All mice 
A
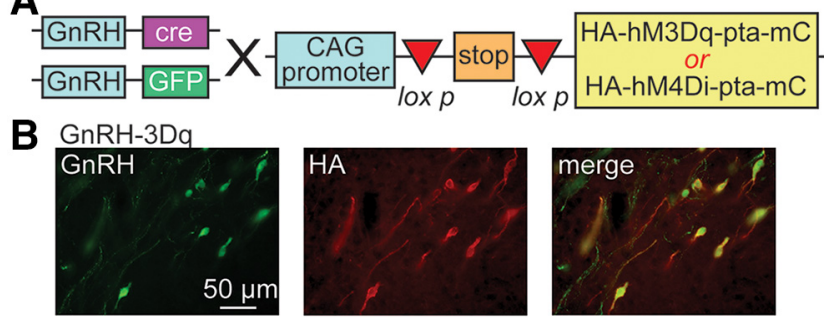

GnRH-4Di
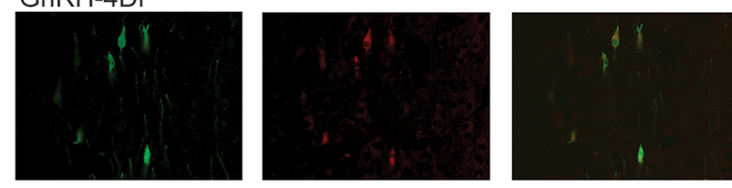

C GnRH-GFP-3Dq CNO

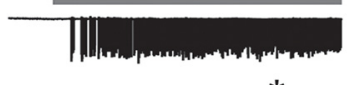

D GnRH-GFP-4Di
CNO
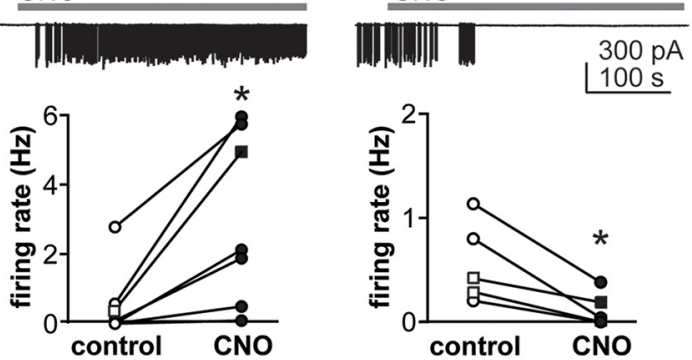

Figure 1. DREADD expression and function in $\mathrm{GnRH}$ neurons. $\boldsymbol{A}$, Mice homozygous for Cre and GFP were bred to mice expressing either the 3Dq or 4Di under the CAG promoter; $\mathrm{mC}$, mCitrine. $\boldsymbol{B}$, Dual immunofluorescence for $\mathrm{GnRH}$ (green) and $\mathrm{HA}$ tag (red) in P14 female GnRH-3Dq (top) and GnRH-4Di (bottom) female mice. $\boldsymbol{C}, \boldsymbol{D}, \mathrm{CNO}$ alters $\mathrm{GnRH}$ neuron firing rate in vitro in $\mathrm{GnRH}-\mathrm{GFP}-3 \mathrm{Dq}(\boldsymbol{C})$ and $\mathrm{GnRH}-\mathrm{GFP}-4 \mathrm{Di}(\boldsymbol{D})$ mice. Scale bar is the same in $\boldsymbol{C}, \boldsymbol{D}$; open symbols, control; closed symbols, CNO treatment. Circles show adults, squares prepubertal mice; $* p<0.05$ two-tailed Wilcoxon matched-pair signed-rank test $(\boldsymbol{C})$, two-tailed paired Student's $t$ test $(\boldsymbol{D})$.

had ad libitum access to water and chow (Teklad 2916, breeders received high protein 2919 chow, Envigo). Mice were housed on a 14/10 h light/dark cycle with time of lights on at 0300 Eastern Standard Time. Some mice were ovariectomized (OVX) for LH assay studies, and some mice received subcutaneous osmotic pumps that were removed one week later (procedure described below). Surgery was done under isoflurane anesthesia and bupivacaine applied as a local analgesic. PNA mice were generated as described (Sullivan and Moenter, 2004; Dulka and Moenter,

Table 1: Genotypes of mice and in text abbreviation used

\begin{tabular}{|c|c|}
\hline Abbreviation & Genotype \\
\hline GnRH-Cre & $\mathrm{GnRH}-\mathrm{Cre}^{+/+}$or $\mathrm{GnRH}-\mathrm{Cre}^{+/-}$ \\
\hline GnRH-GFP & $\mathrm{GnRH} \mathrm{GFP}^{+/+}$or GnRH-GFP ${ }^{+/-}$ \\
\hline GnRH-Cre/GnRH-GFP & $\mathrm{GnRH}-\mathrm{Cre}^{+/+} / \mathrm{GnRH}-\mathrm{GFP}^{+/+}$ \\
\hline GnRH-4Di & $\mathrm{GnRH}-\mathrm{Cre}^{+/-} / \mathrm{CAG}-\mathrm{hM} 4 \mathrm{Di}^{+/-}$ \\
\hline GnRH-3Dq & GnRH-Cre ${ }^{+/-} / \mathrm{CAG}-\mathrm{hM} \mathrm{Dq}^{+/-}$ \\
\hline GnRH-GFP-4Di & $\begin{array}{l}\mathrm{GnRH}-\mathrm{Cre}^{+/-} / \mathrm{GnRH}-\mathrm{GFP}^{+/-} / \mathrm{CAG}- \\
\mathrm{hM} 4 \mathrm{Di}^{+/-}\end{array}$ \\
\hline GnRH-GFP-3Dq & $\begin{array}{l}\mathrm{GnRH}-\mathrm{Cre}^{+/-} / \mathrm{GnRH}-\mathrm{GFP}^{+/-} / \mathrm{CAG}- \\
\mathrm{hM} \mathrm{Dq}^{+/-}\end{array}$ \\
\hline
\end{tabular}

2017). In brief, male C57BI/6J mice were crossed with female GnRH-GFP mice. Pregnant GnRH-GFP female mice were injected subcutaneously with $225 \mu \mathrm{g}$ dihydrotestosterone (DHT; $5 \alpha$-androstan-17 $\beta$-ol-3-one) in sesame oil on days $16-18$ of gestation ( $d 1=$ copulatory plug). Control groups included mice injected with sesame oil vehicle and uninjected dams. As previously reported (Roland et al., 2010; Roland and Moenter, 2011; Dulka and Moenter, 2017; Berg et al., 2018; Dulka et al., 2020), no difference (all $p>0.1$ ) was observed between offspring of uninjected and vehicle-treated dams [GnRH-GFP-4Di: cycles twoway, repeated-measures ANOVA control vs vehicle $F_{(1,9)}=$ 0.5455; GnRH-GFP-3Dq: vaginal opening (VO) two-way ANOVA control vs vehicle $F_{(1,32)}=1.802$, first estrus $F_{(1,30)}$ $=0.7714$, extracellular recordings two-way ANOVA $F_{(1,12)}=$ 3.063 , cycles three-way, repeated-measures ANOVA $F_{(1,13)}$ $=0.6290$; all other groups had only uninjected offspring in the control groups]. Data from these groups were thus combined and reported as controls. A second dam (CD1 background strain) was included in all breeding cages for maternal and nutritional support to increase survival of PNA pups; combined litters were adjusted to $<15$ pups by culling CD1 pups, which are phenotypically distinct, to normalize nutrition. The Institutional Animal Care and Use Committee of the University of Michigan (PRO00006816/ PRO00008797) approved all animal procedures.

\section{Immunohistochemistry}

To assess expression of DREADD receptors in GnRH neurons, GnRH-3Dq mice and GnRH-4Di mice were perfused transcardially with $4 \%$ paraformaldehyde (Fisher) on postnatal day (P)14 or during adulthood. Brains were post fixed for $4-24 \mathrm{~h}$ at $4^{\circ} \mathrm{C}$, then stored in $20 \%$ sucrose with $0.01 \%$ sodium azide, for at least $12 \mathrm{~h}$ for cryoprotection. Brains were sectioned at $30 \mu \mathrm{m}$ into five series on a SM2010 R freezing microtome (Leica Biosystems). Sections were taken from just caudal to the olfactory bulb through the optic chiasm for use in free-floating dual immunofluorescence using standard procedures (Bellefontaine et al., 2014). The primary antibodies used (Table 2) were rat anti-HA high-affinity (1:1000, Roche) and rabbit anti-GnRH (EL-14, RRID: AB 2715535, 1:10,000; generous gift from Oline Rønnekleiv, Oregon Health and Science University, Portland, OR; Ellinwood et al., 1985). Primary antibodies were visualized with Alexa Fluor 546/594-conjugated goat anti-rat and Alexa Fluor 488-conjugated goat anti-rabbit (A-11081 and A11034 , Thermo Fisher Scientific), respectively. For visualization of the DREADD receptor in GnRH-4Di and GnRH-3Dq mice, sections were mounted on Superfrost Plus glass slides (Thermo Fisher Scientific) and coverslipped with ProLong Gold antifade reagent containing 4',6-diamidino-2-phenylindole (Thermo Fisher Scientific). Immunofluorescence was detected using a fluorescent Axio Imager microscope (Zeiss). The number of cells expressing $\mathrm{GnRH}$, HA, or both was counted in all sections from a single series from each mouse.

\section{Tail-tip blood collection and LH measurements}

All mice used for blood sampling were handled for at least two weeks before experiments. Tail-tip blood 
Table 2: Antibodies used for detection of DREADD expression in GnRH neurons

\begin{tabular}{|c|c|c|c|c|}
\hline Peptide target & Antigen sequence & Name of antibody & $\begin{array}{l}\text { Source, catalog number, RRID } \\
\text { information }\end{array}$ & Species/type \\
\hline $\mathrm{GnRH}$ & $\begin{array}{l}\text { GnRH conjugated to bo- } \\
\text { vine serum albumin }\end{array}$ & EL-14 & $\begin{array}{l}\text { Dr. Oline Rønnekleiv, Oregon Health and } \\
\text { Science University, RRID: AB_2715535 }\end{array}$ & $\begin{array}{l}\text { Rabbit/ } \\
\text { polyclonal }\end{array}$ \\
\hline
\end{tabular}

collection was performed as described (Czieselsky et al., 2016). After a small nick at the tail tip, mice were placed on a flat surface and allowed to roam freely while $6 \mu$ of tail blood was collected and immediately mixed with $54 \mu \mathrm{l}$ of $0.1 \mathrm{M}$ PBS (Invitrogen) containing $0.05 \%$ Tween 20 and $0.2 \%$ BSA (Jackson ImmunoResearch). Samples were kept on ice during blood collection then stored at $-20^{\circ} \mathrm{C}$ until LH assay. Intraassay CV was $2.2 \%$ and interassay CVs were $7.3 \%$ [low quality control (QC), $0.13 \mathrm{ng} / \mathrm{ml}$ ], 5.0\% (medium QC, $0.8 \mathrm{ng} / \mathrm{ml}$ ), and 6.5\% (high QC, $2.3 \mathrm{ng} /$ $\mathrm{ml}$ ). Functional sensitivity was $0.016 \mathrm{ng} / \mathrm{ml}$ (Steyn et al., 2013). In some experiments, immediately following the last sample of the frequent sampling period, mice received a single injection of $\mathrm{GnRH}(150-200 \mathrm{ng} / \mathrm{kg}$, i.p.; Bachem), and blood was collected 15 min later to test pituitary LH response.

\section{Control experiments to test the bioactivity of DREADDs expressed in GnRH neurons}

\section{Experiment 1}

To test the effect of $\mathrm{CNO}$ on $\mathrm{GnRH}$ neuron firing rate, basal $\mathrm{GnRH}$ activity was measured for $10 \mathrm{~min}$ via extracellular recordings (described below) followed by bath application of CNO $(0.2-1 \mu \mathrm{M})$ for at least $10 \mathrm{~min}$ in brain slices from prepubertal (P14 and P21) and adult mice. Firing rate was quantified during the final 4 min before CNO treatment and for minutes 7 through 10 inclusive during CNO treatment $(n=7$ cells for GnRH-GFP-3Dq and $n=5$ cells for $\mathrm{GnRH}-\mathrm{GFP}-4 \mathrm{Di})$. Data from each age group within a genotype were combined.

\section{Experiment 2: hM4Di (4Di)}

To study whether activation of the 4Di DREADD targeted to $\mathrm{GnRH}$ neurons could decrease $\mathrm{LH}$ in vivo, adult female $\mathrm{GnRH}-\mathrm{Cre}(n=4)$ and $\mathrm{GnRH}-4 \mathrm{Di}(n=3)$ mice were OVX to elevate episodic LH release. Twelve to $20 \mathrm{~d}$ later, tail blood for LH assay was sampled at 6-min intervals for $174 \mathrm{~min}$. Mice were sampled for $54 \mathrm{~min}$ without treatment, then received an intraperitoneal saline injection to assess the potential effects of stress attributable to injection, followed at $114 \mathrm{~min}$ by $\mathrm{CNO}(0.3 \mathrm{mg} / \mathrm{kg}$ or $1 \mathrm{mg} / \mathrm{kg}$, i.p.; Enzo Life Sciences or Tocris) and then $\mathrm{GnRH}$ at $180 \mathrm{~min}$. LH pulses were detected by a version of Cluster (Veldhuis and Johnson, 1986) running in IgorPro using cluster sizes of two points for both peak and nadir and $t$ scores of 2 for detection of increases and decreases.

\section{Experiment 3}

CNO can be metabolized to clozapine, which can alter function of central neural systems independent of DREADD receptors (Gomez et al., 2017). To test whether clozapine alters $\mathrm{LH}$ release, ovary-intact $\mathrm{GnRH}-\mathrm{Cre}$ mice without either DREADD $(n=2)$ were sampled at 6-min intervals for $114 \mathrm{~min}$ and were given $0.95 \mathrm{mg} / \mathrm{kg}$ clozapine (Tocris) intraperitoneally at $54 \mathrm{~min}$. Mean LH values before and after clozapine were compared. To test whether clozapine can alter $\mathrm{GnRH}$ neuron firing rate, clozapine (1 $\mu \mathrm{M})$ was bath applied during extracellular recordings of $\mathrm{GnRH}$ neurons in GnRH-GFP mice and firing rate assessed as in experiment 1 .

\section{Experiment 4: hM3Dq (3Dq)}

To test if activation of 3Dq DREADD targeted to $\mathrm{GnRH}$ neurons could increase LH, ovary-intact $\mathrm{GnRH}-\mathrm{Cre}$ and $\mathrm{GnRH}-3 \mathrm{Dq}$ females ( $n=3$ each) were sampled at 6-min intervals for $132 \mathrm{~min}$. CNO (1 mg/kg, i.p.) was given at 54 min. To test whether changes in $\mathrm{LH}$ were $\mathrm{GnRH}$ dependent, ovary-intact $\mathrm{GnRH}-3 \mathrm{Dq}$ females $(n=2)$ were injected with the $\mathrm{GnRH}$ receptor antagonist Antide (3 mg/ $\mathrm{kg}$, s.c.) $1.25 \mathrm{~h}$ before sampling began; CNO (1 mg/kg, i.p.) was given $30 \mathrm{~min}$ after sampling began. To test whether elevated $\mathrm{LH}$ levels were sustained and whether a lower dosage of CNO $(0.3 \mathrm{mg} / \mathrm{kg})$ was able to elicit a similar rise in $\mathrm{LH}$, ovary-intact $\mathrm{GnRH}-3 \mathrm{Dq}$ females $(n=2)$ were sampled every $6 \mathrm{~min}$ for $96 \mathrm{~min}$ then every $30 \mathrm{~min}$ for an additional $5 \mathrm{~h}$ with one additional sample at $7.5 \mathrm{~h}$. CNO $(0.3 \mathrm{mg} / \mathrm{kg}$, i.p.) was injected at $30 \mathrm{~min}$.

\section{Main experiments to test the role of manipulating GnRH neuron activity with DREADDs}

The below manipulations were the same for $\mathrm{GnRH}$ GFP-4Di and GnRH-GFP-3Dq mice with the exception that PNA mice were included in the latter experiments. Because PNA treatment suppresses $\mathrm{GnRH}$ neuron firing rate before puberty (Dulka and Moenter, 2017), no attempt was made to further suppress $\mathrm{GnRH}$ neuron activity in GnRH-GFP-4Di mice.

\section{Prepubertal CNO injections and osmopump placement}

To study the role of manipulating $\mathrm{GnRH}$ neuron activity before puberty, GnRH-GFP-4Di or GnRH-GFP-3Dq mice received either intraperitoneal injections of CNO $12 \mathrm{~h}$ apart at a dosage of $0.3 \mathrm{mg} / \mathrm{kg}$ or a miniosmotic pump implant (Alzet, 1007D: flow of $0.5 \mu \mathrm{l} / \mathrm{h}$ for up to $7 \mathrm{~d}$ ) beginning at two weeks of age. Osmopumps were filled with $100 \mu \mathrm{l}$ of either $0.5 \mu \mathrm{g} / \mu \mathrm{l} \mathrm{CNO}$ in saline with $2.57 \%$ DMSO or saline+DMSO vehicle solution. Before surgery, all pups in a litter were removed from the dams' cage including the pups of the CD1 foster dam. Mice in which osmopumps were inserted underwent anesthesia with 
$2-3 \%$ isoflurane and a longitudinal incision was made on the animal's back and the osmospump inserted subcutaneously. Immediately before insertion, the pump was immersed in sterile $0.9 \%$ saline solution to ease insertion. Bupivacaine was applied post operatively as a local analgesic and Carprofen ( $5 \mathrm{mg} / \mathrm{kg}$, sc; Zoetis Petcare) was given both before surgery and $24 \mathrm{~h}$ later. The incision was closed with wound clips. Mice were allowed to fully recover before being placed back with other pups and subsequently the entire litter was returned to the dam. At three weeks of age, pups were weaned and either pumps were removed using the same anesthesia and analgesia protocol or injections were ceased.

\section{Analysis of reproductive parameters}

To test whether changing postnatal firing of $\mathrm{GnRH}$ neurons altered reproductive parameters, day of VO was monitored upon starting CNO injections or after osmopump insertion surgery at P14; no mouse had VO during the duration of injections or before osmopump removal at P21. Upon VO, vaginal lavage was used to determine day of first estrus. Estrous cycles were assessed by daily vaginal lavage from 9 to 12 weeks of age.

\section{Brain slice preparation}

Solutions were bubbled with $95 \% \mathrm{O}_{2} / 5 \% \mathrm{CO}_{2}$ throughout the duration of experiments and at least 15 min before tissue exposure to solutions. Slices were made between 8:30 A.M. and 12 P.M. The brain was rapidly removed and placed in ice-cold sucrose saline solution containing the following: $250 \mathrm{~mm}$ sucrose, $3.5 \mathrm{~mm} \mathrm{KCl}, 26 \mathrm{~mm} \mathrm{NaHCO}_{3}$, $10 \mathrm{~mm}$ D-glucose, $1.25 \mathrm{~mm} \mathrm{NaH}_{2} \mathrm{PO}_{4}, 1.2 \mathrm{~mm} \mathrm{MgSO}_{4}$, and $3.8 \mathrm{~mm} \mathrm{MgCl} 2$. Coronal $(300 \mu \mathrm{m})$ slices were cut with a Leica VT1200S vibrating slicer (Leica Biosystems). Slices were incubated in a 1:1 mixture of sucrose saline and artificial CSF (ACSF) containing the following: $135 \mathrm{~mm} \mathrm{NaCl}$, $3.5 \mathrm{~mm} \mathrm{KCl}, 26 \mathrm{~mm} \mathrm{NaHCO} 3,10 \mathrm{~mm}$ D-glucose, $1.25 \mathrm{~mm}$ $\mathrm{Na}_{2} \mathrm{HPO}_{4}, 1.2 \mathrm{~mm} \mathrm{MgSO}_{4}$, and $2.5 \mathrm{~mm} \mathrm{CaCl}$ ( $\mathrm{pH}$ 7.4) for $30 \mathrm{~min}$ at room temperature $\left(21-23^{\circ} \mathrm{C}\right)$ and then transferred to $100 \%$ ACSF for an additional $30 \mathrm{~min}$ at room temperature before recording. Recordings were performed $1-5 \mathrm{~h}$ after brain slice preparation; no difference in firing patterns were evident based on time after brain slice preparation.

\section{Extracellular recordings}

Extracellular recordings were made to monitor spontaneous action potential firing (Nunemaker et al., 2003; Alcami et al., 2012; Dulka and Moenter, 2017). Slices were placed in a chamber continuously perfused with ACSF $(2-3 \mathrm{ml} / \mathrm{min})$ and heated to $30-32^{\circ} \mathrm{C}$ with an inlineheating unit (Warner Instruments). To identify $\mathrm{GnRH}$ neurons, an Olympus BX51WI microscope was used to briefly illuminate GFP-positive cells in the preoptic area at $488 \mathrm{~nm}$. A Flaming/Brown P-97 puller (Sutter Instruments) was used to pull borosilicate capillary glass (type 7052, $1.65-\mathrm{mm}$ outer diameter and 1.12-mm inner diameter; World Precision Instruments) into recording micropipettes with a resistance of 2-4 M 2 . Micropipettes used for recordings were filled with a HEPES-buffered solution containing the following: $150 \mathrm{~mm} \mathrm{NaCl}, 10 \mathrm{~mm}$ HEPES, 10 $\mathrm{mm}$ D-glucose, $2.5 \mathrm{~mm} \mathrm{CaCl}_{2}, 1.3 \mathrm{~mm} \mathrm{MgCl}_{2}$, and $3.5 \mathrm{~mm}$ $\mathrm{KCl}$. All recordings were conducted on one channel of an EPC-10 dual patch clamp amplifier using Patchmaster software (HEKA Elektronik) running on a Macintosh computer. Low resistance seals $(<30 \mathrm{M} \Omega)$ were formed between the pipette and neuron after first exposing the pipette to the slice tissue in the absence of positive pressure. Recordings were made in voltage-clamp mode with a $0-\mathrm{mV}$ pipette holding potential and signals acquired at $10 \mathrm{kHz}$ and filtered at $5 \mathrm{kHz}$. Recording stability and loose seal were checked every $10 \mathrm{~min}$ by current response to a 5-mV hyperpolarizing voltage step. Inactive cells were treated with high-potassium ACSF $(20 \mathrm{~mm}$ $\left.\mathrm{K}^{+}\right)$. Cells that exhibited action currents in response to $\mathrm{K}^{+}$were verified to be alive and recordable, and thus quiescence data were included in analysis. For cells not responding to $\mathrm{K}^{+}$, data analysis was truncated at the last observed action current. One-hour recordings of GFPidentified $\mathrm{GnRH}$ neurons were made. No more than three extracellular recordings per animal and two cells per slice were included for analysis, and at least four mice from at least three different litters were tested per group. Variation within an animal or among littermates was not less than among all animals within a group. Cell location was mapped to an atlas (Sidman et al., 1971) after recording; no differences in recording observations were attributable to location.

\section{Whole-cell patch-clamp}

Pipettes were pulled as described above and resistance was 2-4 M $\Omega$ when filled with the following: $140 \mathrm{~mm}$ $\mathrm{KCl}, 10 \mathrm{~mm}$ HEPES, $5 \mathrm{~mm}$ EGTA, $0.1 \mathrm{~mm} \mathrm{CaCl} 2,4 \mathrm{~mm}$ MgATP, and $0.4 \mathrm{~mm} \mathrm{NaGTP,} 300 \mathrm{mOsm}$, pH 7.2 with $\mathrm{NaOH}$ for recording GABAergic postsynaptic currents (PSCs). Pipettes were wrapped with Parafilm (Bemis) to reduce capacitive transients; remaining transients were electronically cancelled. A liquid junction potential of $-4.9 \mathrm{mV}$ was corrected online during all recordings. After achieving a $>1-G \Omega$ seal and the whole-cell configuration, membrane potential was held at $-65 \mathrm{mV}$. Series resistance (Rs), input resistance (Rin), and holding current (Ihold) were measured every $2-3$ min using a $5-\mathrm{mV}$ hyperpolarizing step from $-65 \mathrm{mV}$ (mean of 16 repeats, $20-\mathrm{ms}$ duration, sampled at $100 \mathrm{kHz}$, and filtered at $10 \mathrm{kHz}$ ). Only recordings with a Rin of $>400 \mathrm{M} \Omega$, lhold of $-85-20 \mathrm{pA}$, stable Rs of $<20 \mathrm{M} \Omega$, and a stable membrane capacitance $(\mathrm{Cm})$ between 8.5 and $22 \mathrm{pF}$ were used for analysis. Spontaneous GABAergic PSCs (sPSCs) were monitored in voltage-clamp mode at a holding potential of $-65 \mathrm{mV}$. Current was sampled at $20 \mathrm{kHz}$ and filtered at $10 \mathrm{kHz}$. ACSF contained $20 \mu \mathrm{m}$ DAPV (Tocris), and $10 \mu \mathrm{m} C N Q X$ to block ionotropic glutamate receptors. At least two 120-s recordings were made for each cell to determine SPSC frequency. To measure activity-independent miniature PSCs (mPSCs), two to three 120-s recordings were made in the presence of $0.5 \mu \mathrm{m}$ tetrodotoxin (TTX; Tocris). 

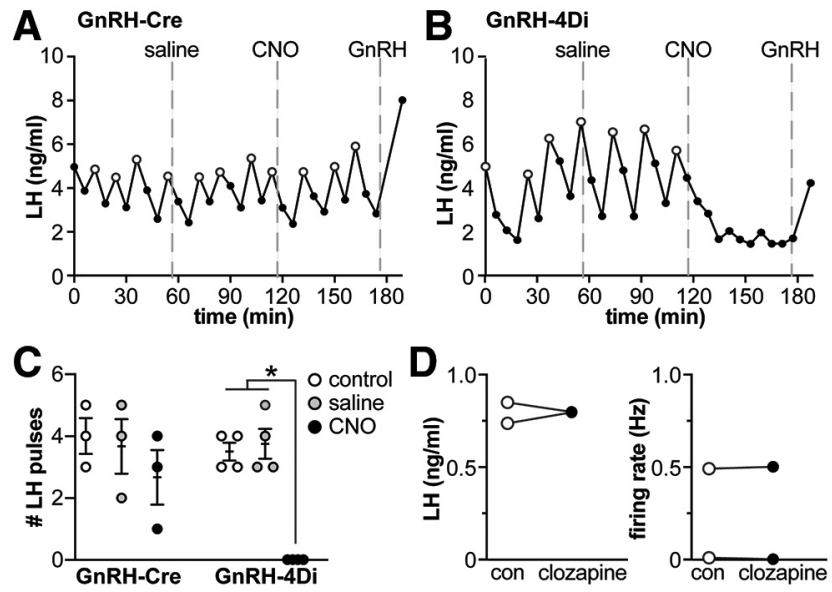

Figure 2. Activation of $4 \mathrm{Di}$-coupled DREADDs targeted to $\mathrm{GnRH}$ neurons reduces $\mathrm{LH}$. $\boldsymbol{A}, \boldsymbol{B}$, $\mathrm{LH}$ pulse patterns in OVX $\mathrm{GnRH}-\mathrm{Cre}$ mice $(\boldsymbol{A})$ or OVX GnRH-4Di mice $(\boldsymbol{B})$ during a control period, after intraperitoneal saline injection, after intraperitoneal CNO $(1 \mathrm{mg} / \mathrm{kg})$ injection, and after intraperitoneal GnRH (150-200 ng/kg) injection. Cluster detected pulses before $\mathrm{GnRH}$ treatment are shown as white symbols, dashed gray lines show times of intraperitoneal injections. $\boldsymbol{C}$, Individual values and mean \pm SEM number of $\mathrm{LH}$ pulses during the three treatment periods in $\boldsymbol{A}, \boldsymbol{B}$, two-way repeated-measures ANOVA (interaction $F_{(2,10)}=6.820, p=0.0135$; genotype $F_{(1,5)}=2.770, p=0.1569$; treatment $F_{(2,10)}=24.86$, $p=0.0001$; subject $F_{(5,10)}=3.716, p=0.0368$, Sidak post hoc; $* p<0.0001)$. $\boldsymbol{D}$, left, Mean LH values in samples before and after intraperitoneal injection of $0.95 \mathrm{mg} / \mathrm{ml}$ clozapine to $\mathrm{GnRH}$-Cre mice. Right, Mean $\mathrm{GnRH}$ neuron firing rate for $4 \mathrm{~min}$ before and minutes 7-10 during $1 \mu \mathrm{m}$ clozapine treatment.

\section{Analysis}

Action currents or PSCs were detected off-line using custom programs in Igor Pro 6.31 and 7.02 (Wavemetrics). Extracellular data were binned at $60-\mathrm{s}$ intervals and were transferred to Excel (Microsoft). Mean firing rate $(\mathrm{Hz})$ and PSC frequency were calculated by dividing the total number of events by the duration of recording. For PSCs, amplitude, interval, rise time, decay, and full-width half-maximum (FWHM) are also reported. Rise time was quantified from baseline to half of the maximum amplitude of the PSC. Decay time was calculated as the time between $90 \%$ and $10 \%$ of the maximum current amplitude.

\section{Statistics}

Statistical analyses were performed using Prism 8 (GraphPad Software). Data are reported as individual values with mean \pm SEM. Data distributions were tested using a Shapiro-Wilk normality test. The null hypothesis was rejected if $p<0.05$, and exact $p$ values $<0.1$ are reported. Specific tests were selected based on experimental design and data distribution and are indicated in the results.

\section{Results}

\section{DREADD receptors are effectively targeted to GnRH neurons}

To verify DREADD expression was present in $\mathrm{GnRH}$ neurons at the same prepubertal age that CNO was
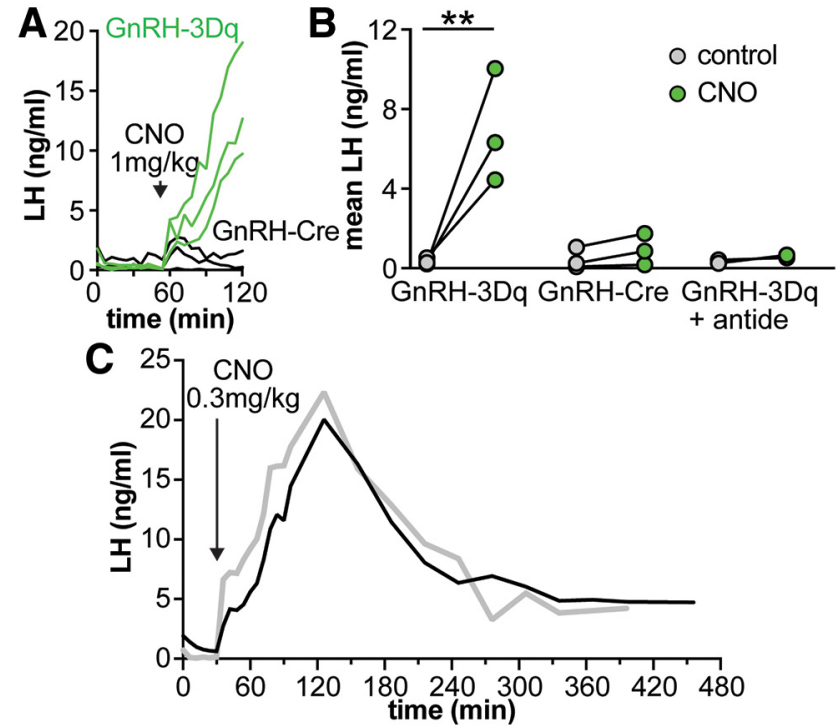

Figure 3. $\mathrm{CNO}$ induces $\mathrm{LH}$ release in $\mathrm{GnRH}-3 \mathrm{Dq}$ mice in a $\mathrm{GnRH}$ dependent manner. $\boldsymbol{A}$, $\mathrm{LH}$ profiles in three $\mathrm{GnRH}-\mathrm{Cre}$ (black) and three $\mathrm{GnRH}-3 \mathrm{Dq}$ mice (green) before and after intraperitoneal CNO injection (1 mg/kg; arrow). B, Mean LH in 10 samples before (control) and after CNO injection (left and center) and six samples before and after CNO (right). Two-way repeated-measures ANOVA (interaction $F_{(2,5)}=10, p=0.0174$; genotype $F_{(2,5)}=9.6, p=0.0192$; treatment $F_{(1,5)}=13, p=0.0165$; subject $F_{(5,5)}=1, p=0.5005$, Sidak post hoc; $* * p<0.01)$. C, LH response to $\mathrm{CNO}$ injection $(0.3 \mathrm{mg} / \mathrm{kg})$ remains elevated for several hours after a single injection; black and gray traces are from two separate animals tested.

administered in the present studies, dual immunofluorescence for GnRH peptide and the HA-tag in the DREADD transgene was performed in $\mathrm{GnRH}-3 \mathrm{Dq}$ and $\mathrm{GnRH}-4 \mathrm{Di}$ mice without GFP at P14 (Fig. 1B). HA expression was detected in $95 \%$ of $\mathrm{GnRH}$-positive cells in P14 GnRH-3Dq animals $(n=2,139 / 146$ and $141 / 149$ cells) and $94 \%$ of GnRH-positive cells in P14 GnRH-4Di animals ( $n=2,158 /$ 162 and 97/104 cells). These results indicate the majority of $\mathrm{GnRH}$ neurons express the DREADD receptor as expected. DREADD expression was also observed in non-GnRH neurons (GnRH-3Dq, 183 and 186 cells; $\mathrm{GnRH}-4 \mathrm{Di}, 448$ and 117 cells). These cells were in the lateral septum; this was expected as $\mathrm{GnRH}$ is expressed in this region during development (Skynner et al., 1999), permitting Cre-lox excision of the stop cassette. HA-immunoreactivity in $\mathrm{GnRH}$ neurons extended into processes (Fig. 1B), as well as the median eminence (data not shown).

\section{Results of control experiments to test the bioactivity of DREADDs expressed in GnRH neurons}

\section{Experiment 1}

The efficacy of activating DREADDs with the CNO ligand was first tested in vitro in brain slices. In brain slices from GnRH-GFP-3Dq mice, CNO $(0.2-1 \mu \mathrm{M})$ increased firing rate of GnRH neurons $(n=7$, control $0.6 \pm 0.4 \mathrm{~Hz}$, CNO $3.0 \pm 0.9 \mathrm{~Hz}$, $p=0.0156$ two-tailed Wilcoxon matched-pairs signed-rank test, $W=28$; Fig. 1C). In brain slices from GnRH-GFP-4Di mice, $\mathrm{CNO}(0.2 \mu \mathrm{M})$ decreased firing rate of $\mathrm{GnRH}$ neurons $(n=5$, control $0.6 \pm 0.2 \mathrm{~Hz}, \mathrm{CNO} 0.1 \pm 0.1 \mathrm{~Hz}, p=0.0266$, twotailed paired Student's $t$ test, $t=3.426, \mathrm{df}=4$; Fig. 1D). 

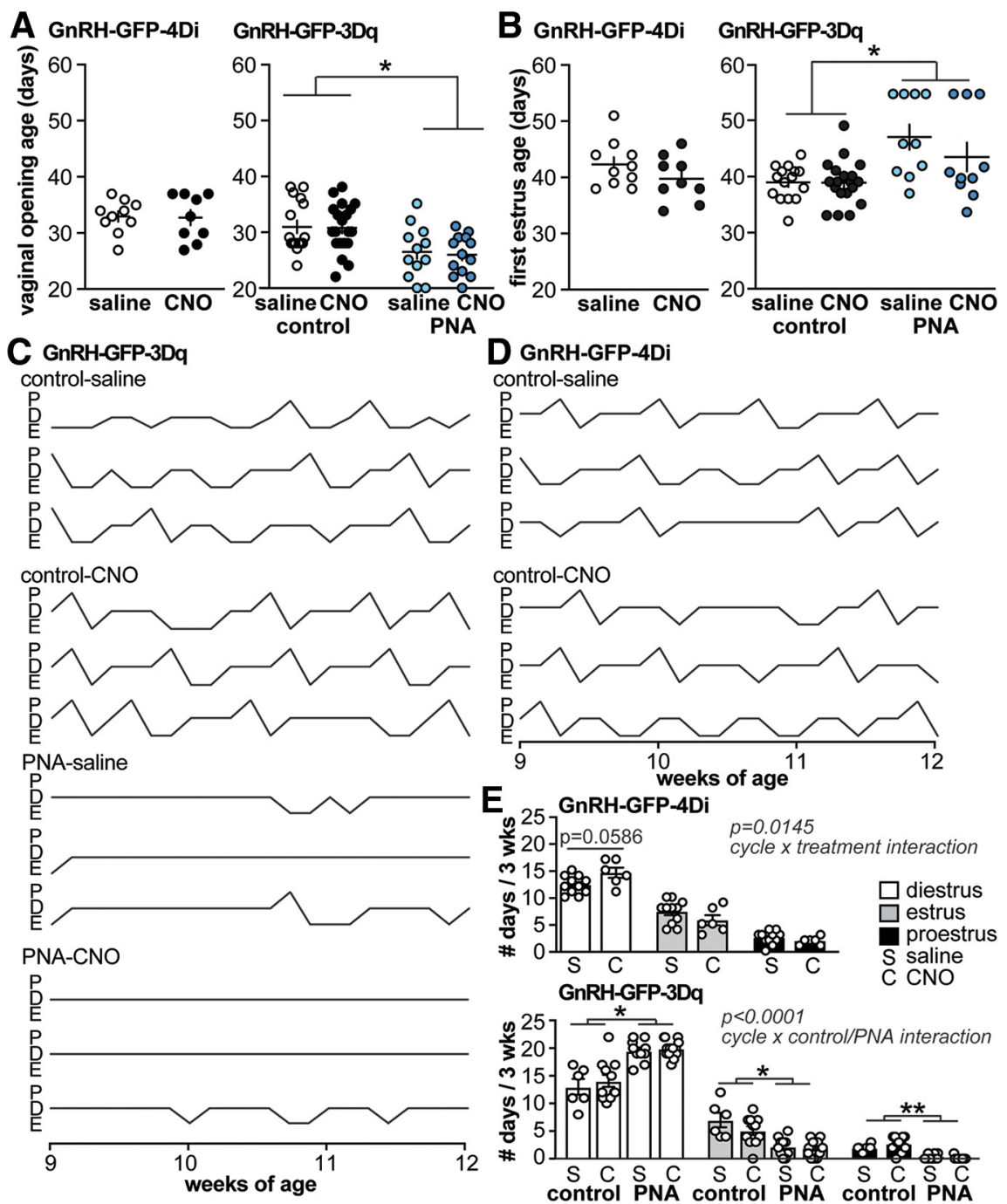

Figure 4. Reproductive parameters are not altered by prepubertal administration of CNO. $\boldsymbol{A}, \boldsymbol{B}$, Age at VO $(\boldsymbol{A})$ and first estrus $(\boldsymbol{B})$ in GnRH-GFP-4Di (left) and GnRH-GFP-3Dq (right) mice; $* p<0.05$ two-way ANOVA/Sidak. $\boldsymbol{C}$, $\boldsymbol{D}$, Representative cycles (P, proestrus; $\mathrm{D}$, diestrus; E, estrus) from GnRH-GFP-3Dq $(\boldsymbol{C})$ and GnRH-GFP-4Di $(\boldsymbol{D})$ mice. $\boldsymbol{E}$, Individual values and mean \pm SEM of number of days spent in each cycle stage; $* p<0.05, * * p<0.01$ three-way repeated-measures ANOVA/Fisher.

\section{Experiment 2: CNO decreases LH pulses in OVX GnRH- 4Di mice}

Baseline LH levels in naturally cycling mice are suppressed by steroidal feedback; therefore, effectiveness of the 4Di DREADD was assessed in OVX mice, which have elevated LH due to release from negative feedback. In GnRH-Cre mice lacking 4Di, neither saline nor CNO $(0.3 \mathrm{mg} / \mathrm{kg})$ altered LH pulses $(n=3$, two-way repeatedmeasures ANOVA/Sidak; for statistical parameters, see legend to Fig. $2 A, C$ ). In contrast, in $\mathrm{GnRH}$-4Di mice, saline had no effect while CNO abolished LH pulses $(n=4$, $p<0.0001$ vs control and saline within subject, two-way repeated-measures ANOVA/Sidak; Fig. 2B,C).

\section{Experiment 3: clozapine does not alter $\mathrm{LH}$ release or}

GnRH neuron firing rate in non-DREADD expressing mice

Studies have suggested that CNO activation of DREADDs may occur via clozapine, a metabolic product of $\mathrm{CNO}$, and that some actions thought to be CNO- mediated may actually be effects of clozapine (Gomez et al., 2017). To determine whether clozapine alters LH levels independent of DREADD expression, we injected ovaryintact $\mathrm{GnRH}$-Cre mice lacking DREADDS with clozapine $(0.95 \mathrm{mg} / \mathrm{kg}$, i.p.). Clozapine had no effect on mean LH levels in vivo or on firing rate of $\mathrm{GnRH}$ neurons in vitro $(n=2$ each; Fig. 2D). This, and the lack of effect of CNO in mice lacking DREADDs, indicates changes in LH are likely attributable to CNO activation of DREADD receptors expressed in $\mathrm{GnRH}$ neurons.

\section{Experiment 4: CNO increases $\mathrm{LH}$ release in $\mathrm{GnRH}-3 \mathrm{Dq}$ mice}

To test whether activation of the 3Dq DREADD in GnRH neurons increased $\mathrm{LH}$ release, $\mathrm{LH}$ pulse sampling was conducted in $\mathrm{GnRH}-\mathrm{Cre}$ and $\mathrm{GnRH}-3 \mathrm{Dq}$ mice which were not OVX. In GnRH-Cre mice lacking 3Dq, LH levels remained near baseline after CNO $(1 \mathrm{mg} / \mathrm{kg})$ injection $(n=3$, $p=0.97$, two-way repeated-measures ANOVA/Sidak; for 
Table 3: Statistical parameters for reproductive measures

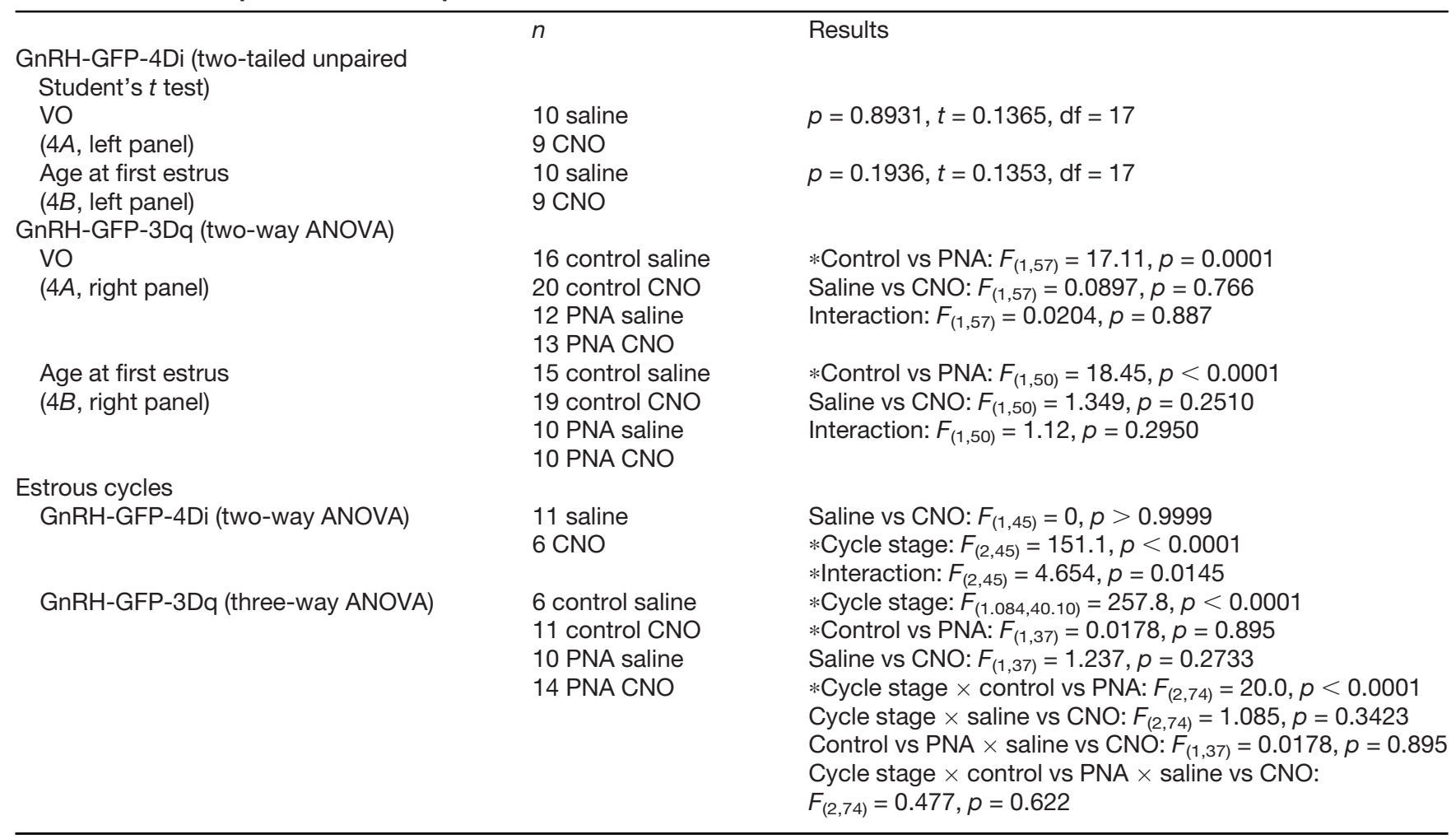

statistical parameters, see legend to Fig. $3 A, B$ ). In $\mathrm{GnRH}-$ $3 \mathrm{Dq}$ mice, in contrast, LH levels rose within 6 min of the injection and remained elevated for the remainder of the sampling period (78 min; $n=3, p<0.01$ two-way ANOVA/ Sidak; Fig. 3A). The CNO-elicited increase was $\mathrm{GnRH}$ dependent, as pretreatment of $\mathrm{GnRH}-3 \mathrm{Dq}$ mice with the $\mathrm{GnRH}$ receptor antagonist Antide $(3 \mathrm{mg} / \mathrm{kg})$ blocked the CNO-elicited LH increase $(n=2, p=0.99$, two-way ANOVA/Sidak; Fig. 3B). Subsequent studies revealed the increase induced by a single CNO injection was maintained for several hours ( $n=2$; Fig. $3 C$ ) and could be elicited by a lower dose $(0.3 \mathrm{mg} / \mathrm{kg})$ of CNO. Thus, CNO effectively activates the reproductive neuroendocrine axis in this animal model and can do so for a prolonged period. The lower dose of $0.3 \mathrm{mg} / \mathrm{kg}$ was used for subsequent experiments to manipulate firing activity in prepubertal mice.

\section{Results of main experiments to test the role of manipulating GnRH neuron activity with DREADDs}

Puberty measures were not affected by altering $\mathrm{GnRH}$ neuron activity during prepubertal development. To assess whether changing $\mathrm{GnRH}$ neuron activity during prepubertal development altered reproduction, three parameters were examined: timing of VO (the first outward sign of puberty), timing of first estrus, and reproductive cycles in adults. CNO was administered from two to three weeks of age via either intraperitoneal injection every $12 \mathrm{~h}$ or osmopump. No difference was observed between treatment methods (two-tailed unpaired Mann-Whitney $U$ or Student's $t$ test as appropriate; data not shown), and these data are combined. Because osmopumps were judged to be less stressful on the mice, some groups were done entirely with osmopumps (i.e., firing rate of GnRH-GFP-3Dq PNA saline and GABAergic PSC recordings in $\mathrm{GnRH}-\mathrm{GFP}-4 \mathrm{Di}$ mice). No differences were observed between saline and CNO treatment in GnRH-GFP4Di or $\mathrm{GnRH}-\mathrm{GFP}-3 \mathrm{Dq}$ control mice in either the age at VO or age at first estrus (Fig. 4A,B, 4Di left panel, 3Dq right panel; Table 3). Despite no difference between saline-treated and CNO-treated GnRH-GFP-3Dq control groups, the expected effects of PNA treatment on VO and first estrus were observed. Specifically, PNA treatment advanced $\mathrm{VO}$ and delayed first estrus, regardless of saline or CNO treatment.

\section{Estrous cycles were mildly altered by inhibiting GnRH neuron activity during prepubertal development}

Estrous cycles were assessed from 9 to 12 weeks of age to determine whether they were altered by modulation of prepubertal $\mathrm{GnRH}$ neuron activity. Representative cycles from each group are displayed in Figure $4 C, D$, quantification of days spent in each cycle stage are shown in Figure 4E, and statistical comparisons are in Table 3. In GnRH-GFP-4Di mice, there was an interaction between cycle stage and treatment (i.e., saline vs CNO), attributable primarily by a mild increase in days spent in diestrus in mice that had been treated with CNO during the prepubertal period. In GnRH-GFP-3Dq mice, there was no effect of saline versus CNO treatment, but the expected difference between cycle stage and animal model (i.e., control vs PNA) was observed (Sullivan and Moenter, 2004; Dulka and Moenter, 2017). Specifically, cyclicity 
A
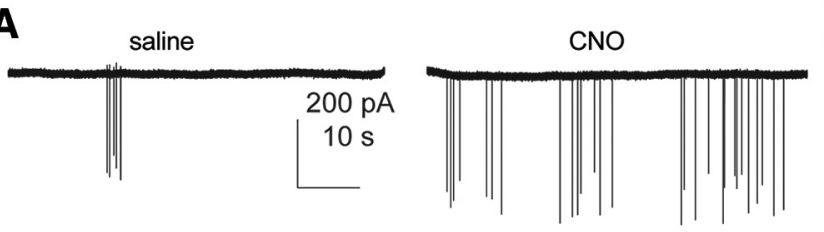

C

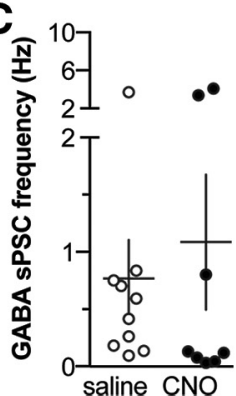

$\mathrm{D}$

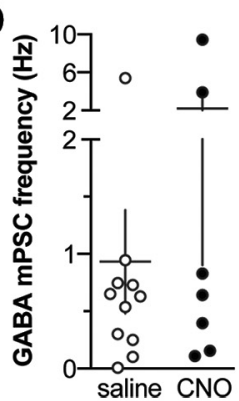

E

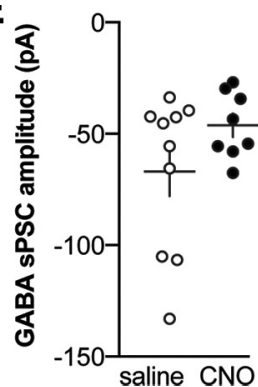

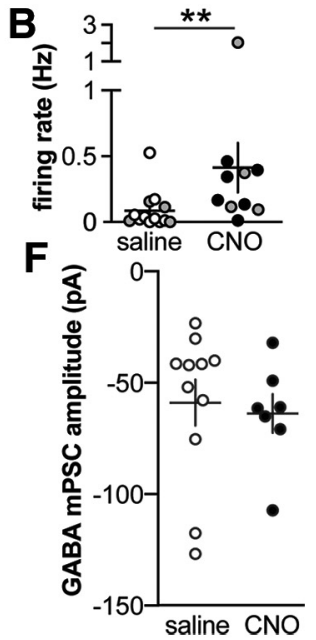

Figure 5. Reducing GnRH neuron activity in GnRH-GFP-4Di mice from two to three weeks of age changes $\mathrm{GnRH}$ neuron firing rate but not GABAergic transmission in adults. $\boldsymbol{A}$, Representative extracellular recordings from each group. $\boldsymbol{B}-\boldsymbol{F}$, Individual values and mean \pm SEM of $\mathrm{GnRH}$ neuron firing rate $(\boldsymbol{B})$, GABA sPSC frequency $(\boldsymbol{C})$, GABA mPSC frequency $(\boldsymbol{D})$, GABA sPSC amplitude $(\boldsymbol{E})$, and GABA mPSC amplitude $(\boldsymbol{F})$ in GnRH-GFP-4Di mice; $* * p<0.01$ two-tailed Mann-Whitney $U$ test. Gray symbols in $\boldsymbol{B}$ indicate mice receiving twice daily intraperitoneal injections of saline or $\mathrm{CNO}$, open and black symbols denote osmopump administration of saline and $\mathrm{CNO}$, respectively. Note that elimination of the cell firing at $>2 \mathrm{~Hz}$ in $\boldsymbol{B}$ does not alter the observation of a significant difference in firing rate.

was disrupted in PNA mice when compared with control animals, with more days in diestrus and fewer days in both estrus and proestrus (three-way ANOVA; Fig. 4E, bottom; Table 3).

\section{Prepubertal reduction of GnRH neuron activity increases $\mathrm{GnRH}$ neuron firing rate in adults but does not alter GABAergic transmission to these cells}

To assess whether decreasing $\mathrm{GnRH}$ neuron firing during the prepubertal period alters adult $\mathrm{GnRH}$ neuron firing and/or GABAergic transmission to $\mathrm{GnRH}$ neurons, electrophysiological recordings were made in brain slices from GnRH-GFP-4Di control mice. Representative recordings from each group are shown in Figure $5 \mathrm{~A}$. CNO treatment from two to three weeks of age increased firing rate of $\mathrm{GnRH}$ neurons from these mice in adulthood (Fig. 5B; Table 4). This result is similar to what has been observed in PNA mice in which the decreased $\mathrm{GnRH}$ neuron activity observed before puberty is correlated with elevated $\mathrm{GnRH}$ neuron activity assessed in adulthood (Roland and Moenter, 2011; Dulka

Table 4: Statistical parameters for comparisons of firing rate and GABAergic PSCs in GnRH-GFP-4Di mice (twotailed Mann-Whitney $U$ test)

\begin{tabular}{|c|c|}
\hline Comparison & $U p$ value \\
\hline \multicolumn{2}{|c|}{ Extracellular recordings } \\
\hline Frequency $(\mathrm{Hz})$ & 12 saline, 9 CNO $16 p=0.0056$ \\
\hline \multicolumn{2}{|c|}{ Spontaneous GABAergic PSCs } \\
\hline Frequency $(\mathrm{Hz})$ & 10 saline, 8 CNO $29 p$ \\
\hline Amp & 10 saline, 8 CNO $39 p$ \\
\hline \multicolumn{2}{|l|}{ Miniature GABAergic } \\
\hline Frequency $(\mathrm{Hz})$ & 11 saline, 7 CNO 33 \\
\hline Amplitude (pA) & 11 saline, 7 CNO $28 p=0.3749$ \\
\hline
\end{tabular}

and Moenter, 2017). We therefore tested whether GABAergic transmission was also elevated in adulthood following prepubertal suppression of $\mathrm{GnRH}$ neurons as is observed in adult PNA mice (Sullivan and Moenter, 2004; Berg et al., 2018). There was no change in frequency or amplitude of spontaneous or miniature GABAergic PSCs to GnRH neurons in adults attributable to prepubertal treatment (Fig. 5C-F; Table 4). There were no differences in passive properties between groups (Table 5).

\section{Prepubertal increase of GnRH neuron activity does not alter firing rate in adults}

To assess whether increasing $\mathrm{GnRH}$ neuron activity during the prepubertal period in PNA mice could normalize firing rate in adulthood, electrophysiological recordings were made in acute brain slices from $\mathrm{GnRH}$ GFP-3Dq PNA mice that were given saline or CNO from two to three weeks of age. Representative recordings from each group are shown in Figure 6A. No differences were observed among groups (Fig. 6B; Table 6). Of note, the increased firing rate repeatedly observed in PNA relative to control diestrous mice was not observed (Roland and Moenter, 2011; Dulka and Moenter, 2017; Dulka et al., 2020). Firing rate in cells from salinetreated GnRH-GFP-3Dq control mice appeared elevated. To test this, we compared the firing rate of $\mathrm{GnRH}$ neurons in these mice to the saline-treated GnRH-GFP4Di mice from this study and diestrous control groups from two prior studies in which animals were naive (unmanipulated; Dulka and Moenter, 2017) or sham OVX (Dulka et al., 2020). This comparison revealed the firing rate of cells from GnRH-GFP-3Dq controls was indeed elevated (Fig. 6C; Table 6). This observation suggests 
Table 5: Passive property values and comparisons for GABAergic sPSC and mPSC recordings in GnRH-GFP-4Di mice (mean \pm SEM, $p$ values from two-tailed unpaired Student's $t$ test with or without Welch correction)

\begin{tabular}{|c|c|c|c|c|c|}
\hline & Saline & $\mathrm{CNO}$ & $p$ value* & $t$ & df \\
\hline \multicolumn{6}{|c|}{ Spontaneous GABAergic PSCs } \\
\hline Series resistance $(\mathrm{M} \Omega)$ & $12.8 \pm 0.9$ & $11.4 \pm 0.7$ & 0.260 & 1.167 & 16 \\
\hline Holding current (pA) & $-54.0 \pm 7.3$ & $-49.0 \pm 6.9$ & 0.629 & 0.492 & 16 \\
\hline Capacitance $(p F)$ & $14.4 \pm 1.2$ & $13.9 \pm 0.5$ & 0.710 & 0.380 & 12.4 \\
\hline \multicolumn{6}{|c|}{ Miniature GABAergic PSCs } \\
\hline Input resistance $(\mathrm{M} \Omega)$ & $681.0 \pm 62.4$ & $734.4 .4 \pm 116.9$ & 0.665 & 0.441 & 16 \\
\hline Holding current (pA) & $-49.4 \pm 4.3$ & $-53.8 \pm 10.5$ & 0.660 & 0.440 & 16 \\
\hline Capacitance $(\mathrm{pF})$ & $13 \pm 1.1$ & $14.7 \pm 1.1$ & 0.609 & 0.522 & 16 \\
\hline
\end{tabular}

* compares listed passive properties between saline and CNO groups.

ligand-independent activation of $3 \mathrm{Dq}$ may occur. Because of this caveat, studies on GABA transmission were not conducted in mice with the 3Dq DREADD targeted to $\mathrm{GnRH}$ neurons.

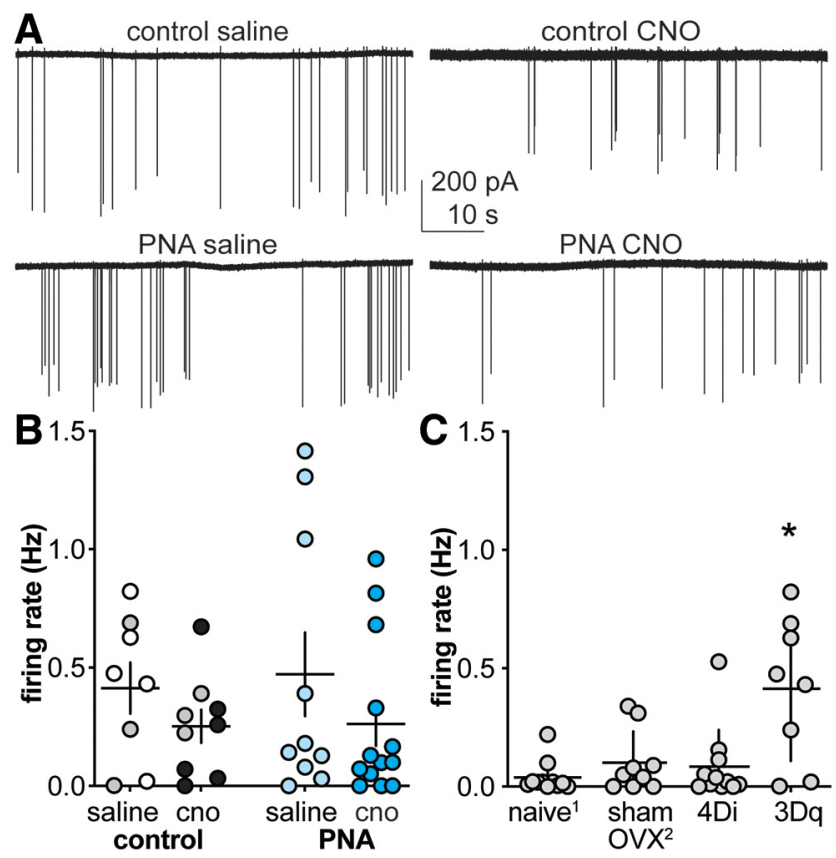

Figure 6. Prepubertal increase of $\mathrm{GnRH}$ neuron activity in $\mathrm{GnRH}-$ GFP-3Dq mice does not alter adult GnRH neuron activity when compared with controls, but expression of the 3Dq receptor increases control GnRH neuron activity. $\boldsymbol{A}$, Representative extracellular recordings from each group. $\boldsymbol{B}$, Individual values and mean \pm SEM GnRH neuron firing rate for GnRH-GFP-3Dq mice. Gray symbols in $\boldsymbol{B}$ indicate mice receiving twice daily intraperitoneal injections of saline or CNO, open symbols denote osmopump administration of saline and black symbols osmopump administration of CNO; all PNA mice received osmopumps. C, Individual values and mean \pm SEM comparison of firing rate from diestrous vehicle controls over three different experiments examining firing rate versus that in PNA mice. ${ }^{1}$ Naive animals were unmanipulated (data from Dulka and Moenter, 2017); ${ }^{2}$ sham animals received sham OVX surgery (data from Dulka et al., 2020). *Kruskal-Wallis $(\mathrm{KW}=8.361, p=0.0391) /$ Dunn's versus naive $p=0.0169$.

\section{Discussion}

In PNA mice, neurobiological changes before puberty are correlated with alterations in both neurobiology and reproductive function in adulthood. Prior work could not separate the effects of PNA treatment from the effects of subsequent changes in $\mathrm{GnRH}$ neuron activity, specifically reduced $\mathrm{GnRH}$ neuron firing rate before puberty, on these adult outcomes. Here, we used chemogenetics to study the effects of altering prepubertal $\mathrm{GnRH}$ neuron activity in the absence of PNA exposure on later reproductive function. We found that decreasing prepubertal GnRH neuron activity is sufficient to reproduce PNA-induced increases in $\mathrm{GnRH}$ neuron firing rate and shift reproductive cyclicity toward that observed in PNA mice, but not to alter puberty timing or GABAergic transmission in adulthood. In contrast, increasing $\mathrm{GnRH}$ neuron activity during the prepubertal period could not rescue the negative effects of PNA exposure on the reproductive parameters that were examined.

To our knowledge, this is the first study using DREADD expression in $\mathrm{GnRH}$ neurons to modulate their activity. Changes in $\mathrm{LH}$ release in vivo and $\mathrm{GnRH}$ neuron firing in brain slices were as expected for the respective DREADD used. The present work indicates that changing prepubertal activity of $\mathrm{GnRH}$ neurons was indeed able to alter their adult function. Specifically, inhibition of GnRH neuron activity during postnatal/prepubertal development both increased firing rate of these cells in adults and shifted reproductive cycles toward more days in diestrus. Both of these findings are consistent with observations made in the PNA model in which decreased GnRH neuron firing rate before puberty is correlated with increased firing rate and disrupted cycles characterized by extended diestrus in adulthood (Dulka and Moenter, 2017). The present findings extend that observation by demonstrating at least partial causation between the early and later changes in neuronal activity. Similar relationships have been demonstrated elsewhere in the central nervous system, for example, neuronal activity during a critical period of postnatal development is important for proper synaptic innervation of the primary visual cortex and normal adult function in the visual system (Chattopadhyaya et al., 2004). 
Table 6: Two-way ANOVA and Kruskal-Wallis parameters for extracellular recordings in GnRH-GFP-3Dq and GnRH-GFP mice

\begin{tabular}{llll}
\hline Comparison (figure) & Control vs PNA & Saline vs CNO & Interaction \\
$\begin{array}{l}\text { Two-way ANOVA for firing rate }(\mathrm{Hz}) \text { in } \\
\text { GnRH-GFP-3Dq mice }(6 A)\end{array}$ & $F_{(1,35)}=0.021, p=0.885$ & $F_{(1,35)}=1.865, p=0.181$ & $F_{(1,35)}=0.104, p=0.749$ \\
Kruskal-Wallis (KW $=8.361) / D u n n(6 B)$ & Naive vs sham & Naive vs 4Di & Naive vs 3Dq \\
& $p>0.99$ & $p>0.99$ & $p=0.0169$ \\
\hline
\end{tabular}

In PNA mice, suppressed firing rate before puberty is also correlated with increased GABAergic transmission to these cells in adulthood (Sullivan and Moenter, 2004; Berg et al., 2018). No change, however, was observed in spontaneous or miniature GABAergic PSC frequency or amplitude in $\mathrm{GnRH}$ neurons in mice in which prepubertal $\mathrm{GnRH}$ neuron activity was suppressed in the absence of PNA exposure. This suggests increased GABAergic input in PNA mice is at least in part attributable to other androgen-induced programming actions. GnRH neurons are thought to be unable to respond directly to androgens (Herbison et al., 1996). In this regard, arcuate kisspeptin neurons, which are directly androgen responsive (Smith et al., 2005), may play a critical role in generating the input to $\mathrm{GnRH}$ neurons needed to regulate cyclicity (Clarkson et al., 2017; Vanacker et al., 2017). Supporting this, chronic chemogenetic activation of arcuate GABAergic neurons resulted in increased $\mathrm{LH}$ secretion and impaired cyclicity (Silva et al., 2019). Androgens can also increase spine density on CA1 hippocampal neurons in adult male and female rats (Leranth et al., 2004; Cunningham et al., 2007). Anatomic and physiologic evidence suggests synaptic sites on $\mathrm{GnRH}$ neurons are increased in PNA mice (Sullivan and Moenter, 2004; Moore et al., 2015; Berg et al., 2018). Together, these observations raise the possibility that androgens play a stronger role in programing inputs to $\mathrm{GnRH}$ neurons than does androgen-induced suppression of $\mathrm{GnRH}$ neuron activity before puberty. In mice in which 4Di was used to suppress prepubertal $\mathrm{GnRH}$ activity, these cells may undergo homeostatic compensation of intrinsic properties to maintain $\mathrm{GnRH}$ neuron activity at the higher level observed in the absence of increased excitatory GABA drive (DeFazio et al., 2002; Herbison and Moenter, 2011). GABA is the primary fast synaptic input to $\mathrm{GnRH}$ neurons, but changes in glutamatergic inputs and/or those of peptidergic neurons in driving the increased $\mathrm{GnRH}$ neuron activity in these mice cannot be excluded.

In contrast to the partial phenocopy of the PNA treatment achieved by chemogenetically suppressing $\mathrm{GnRH}$ neurons from two to three weeks of age, chemogenetic manipulation of these cells at this time had no effect on adult neuronal firing rate or reproductive cycles. The activating experiments with the 3Dq DREADD were conducted in PNA mice to attempt to "rescue" the reproductive aspects observed in PNA adults by restoring high levels of prepubertal $\mathrm{GnRH}$ neuron activity. These data must be interpreted with caution as $\mathrm{GnRH}$ neuron firing rate was elevated in mice with 3Dq DREADD targeted to these cells even in control mice treated with saline when compared with both the 4Di DREADD cells in the present work and controls from prior studies; notably the presence of the 4Di DREADD did not appear to suppress $\mathrm{GnRH}$ neuron activity in adult controls (Dulka and Moenter, 2017; Dulka et al., 2020).

Neither chemogenetic activation nor suppression of $\mathrm{GnRH}$ neurons from two to three weeks of age altered external markers of puberty that were assessed: the timing of $\mathrm{VO}$ and first estrus. It is possible that the chemogenetic treatment was too proximal to $\mathrm{VO}$ to alter its timing. PNA treatment reduces $\mathrm{GnRH}$ neuron activity at this same time period and advances VO, but these activity changes are subsequent to androgen treatment (Dulka and Moenter, 2017). Together, these observations suggest that changing $\mathrm{GnRH}$ neuron activity alone is not sufficient to alter pubertal markers and that prenatal programming actions of androgens are needed.

There are several cautions to bear in mind when interpreting these results. First, we have no measure of how the degree of suppression induced by 4Di or activation induced by $3 \mathrm{Dq}$ compare to activity levels typically achieved by $\mathrm{GnRH}$ neurons during development in vivo. Failure of complete phenocopy in the 4Di or to observe any effects in the 3Dq mice may be attributable to either overshooting or undershooting the typical physiologic range. Of note, our in vitro controls do indicate these chemogenetic tools induce the expected direction of response. Second, the manipulations may have been done at the wrong time during development to result in later physiologic changes. In this regard, the present treatment period was chosen based on when PNA-induced alterations in $\mathrm{GnRH}$ neuron firing rate occur, and is at an age when activity-dependent synaptic changes have been shown to be important in other systems (Soto et al., 2012; Weinhard et al., 2018). Third, while the GnRH-Cre effectively targeted expression of both DREADDs to $\mathrm{GnRH}$ neurons, with $>95 \%$ of these cells expressing these receptors, DREADDs were also expressed in non-GnRH neurons, particularly in the lateral septum. We thus cannot exclude possible off-target effects from CNO action via these neurons. Fourth, ligand-independent DREADD activation may occur. This has been reported for 4Di (Saloman et al., 2016) and may account for the high firing rate observed in 3Dq adult controls in the present work. Fifth, it is possible that compensatory mechanisms overcome changes induced by developmental changes in $\mathrm{GnRH}$ neuron activity. Finally, there may be a wide range of $\mathrm{GnRH}$ neuron firing rates that can support fairly regular cycles in the absence of other androgen-induced changes.

The present findings suggest that PNA-induced suppression of prepubertal $\mathrm{GnRH}$ neuron activity contributes 
to increased firing rate of these cells in adulthood but that the suppression of activity during development alone is not sufficient to phenocopy the model. This suggests that androgen exposure plays a necessary role in programming reproductive neuroendocrine changes in both the PNA model and, perhaps, in PCOS. This postulate is supported by the observation that increasing androgens in a variety of models used to mimic PCOS produce similar reproductive neuroendocrine outcomes (Dumesic et al., 1997; Foecking et al., 2005; Kauffman et al., 2015; Tata et al., 2018).

\section{References}

Abbott DH, Dumesic DA, Eisner JR, Colman RJ, Kemnitz JW (1998) Insights into the development of polycystic ovary syndrome (PCOS) from studies of prenatally androgenized female rhesus monkeys. Trends Endocrinol Metab 9:62-67.

Alcami P, Franconville R, Llano I, Marty A (2012) Measuring the firing rate of high-resistance neurons with cell-attached recording. $J$ Neurosci 32:3118-3130.

Andreae LC, Burrone J (2014) The role of neuronal activity and transmitter release on synapse formation. Curr Opin Neurobiol 27:4752.

Bellefontaine N, Chachlaki K, Parkash J, Vanacker C, Colledge W, d'Anglemont de Tassigny X, Garthwaite J, Bouret SG, Prevot V (2014) Leptin-dependent neuronal NO signaling in the preoptic hypothalamus facilitates reproduction. J Clin Invest 124:2550-2559.

Berg T, Silveira MA, Moenter SM (2018) Prepubertal development of GABAergic transmission to gonadotropin-releasing hormone $(\mathrm{GnRH})$ neurons and postsynaptic response are altered by prenatal androgenization. J Neurosci 38:2283-2293.

Burt Solorzano CM, McCartney CR, Blank SK, Knudsen KL, Marshall JC (2010) Hyperandrogenaemia in adolescent girls: origins of abnormal gonadotropin-releasing hormone secretion. BJOG 117:143-149.

Chattopadhyaya B, Di Cristo G, Higashiyama H, Knott GW, Kuhlman SJ, Welker E, Huang ZJ (2004) Experience and activity-dependent maturation of perisomatic GABAergic innervation in primary visual cortex during a postnatal critical period. J Neurosci 24:9598-9611.

Clarkson J, Han SY, Piet R, McLennan T, Kane GM, Ng J, Porteous RW, Kim JS, Colledge WH, Iremonger KJ, Herbison AE (2017) Definition of the hypothalamic GnRH pulse generator in mice. Proc Natl Acad Sci USA 114:E10216-E10223.

Collins JS, Beller JP, Burt Solorzano C, Patrie JT, Chang RJ, Marshall JC, McCartney CR (2014) Blunted day-night changes in luteinizing hormone pulse frequency in girls with obesity: the potential role of hyperandrogenemia. J Clin Endocrinol Metab 99:2887-2896.

Cunningham RL, Claiborne BJ, McGinnis MY (2007) Pubertal exposure to anabolic androgenic steroids increases spine densities on neurons in the limbic system of male rats. Neuroscience 150:609615.

Czieselsky K, Prescott M, Porteous R, Campos P, Clarkson J, Steyn FJ, Campbell RE, Herbison AE (2016) Pulse and surge profiles of luteinizing hormone secretion in the mouse. Endocrinology 157:4794-4802.

DeFazio RA, Heger S, Ojeda SR, Moenter SM (2002) Activation of Atype gamma-aminobutyric acid receptors excites gonadotropinreleasing hormone neurons. Mol Endocrinol 16:2872-2891.

Dulka EA, Moenter SM (2017) Prepubertal development of gonadotropin-releasing hormone neuron activity is altered by sex, age, and prenatal androgen exposure. Endocrinology 158:3943-3953.

Dulka EA, Burger LL, Moenter SM (2020) Ovarian androgens maintain high $\mathrm{GnRH}$ neuron firing rate in adult prenatally-androgenized female mice. Endocrinology 161:bqz038.
Dumesic DA, Abbott DH, Eisner JR, Goy RW (1997) Prenatal exposure of female rhesus monkeys to testosterone propionate increases serum luteinizing hormone levels in adulthood. Fertil Steril 67:155-163.

Ellinwood WE, Ronnekleiv OK, Kelly MJ, Resko JA (1985) A new antiserum with conformational specificity for LHRH: usefulness for radioimmunoassay and immunocytochemistry. Peptides 6:45-52.

Foecking EM, Szabo M, Schwartz NB, Levine JE (2005) Neuroendocrine consequences of prenatal androgen exposure in the female rat: absence of luteinizing hormone surges, suppression of progesterone receptor gene expression, and acceleration of the gonadotropinreleasing hormone pulse generator. Biol Reprod 72:1475-1483.

Gomez JL, Bonaventura J, Lesniak W, Mathews WB, Sysa-Shah P, Rodriguez LA, Ellis RJ, Richie CT, Harvey BK, Dannals RF, Pomper MG, Bonci A, Michaelides M (2017) Chemogenetics revealed: DREADD occupancy and activation via converted clozapine. Science 357:503-507.

Hartman KN, Pal SK, Burrone J, Murthy VN (2006) Activity-dependent regulation of inhibitory synaptic transmission in hippocampal neurons. Nat Neurosci 9:642-649.

Herbison AE, Moenter SM (2011) Depolarising and hyperpolarising actions of $\mathrm{GABA}(\mathrm{A})$ receptor activation on gonadotrophin-releasing hormone neurones: towards an emerging consensus. J Neuroendocrinol 23:557-569.

Herbison AE, Skinner DC, Robinson JE, King IS (1996) Androgen receptor-immunoreactive cells in ram hypothalamus: distribution and colocalization patterns with gonadotropin-releasing hormone, somatostatin and tyrosine hydroxylase. Neuroendocrinology 63:120-131.

Katz LC, Shatz CJ (1996) Synaptic activity and the construction of cortical circuits. Science 274:1133-1138.

Kauffman AS, Thackray VG, Ryan GE, Tolson KP, Glidewell-Kenney CA, Semaan SJ, Poling MC, Iwata N, Breen KM, Duleba AJ, Stener-Victorin E, Shimasaki S, Webster NJ, Mellon PL (2015) A novel letrozole model recapitulates both the reproductive and metabolic phenotypes of polycystic ovary syndrome in female mice. Biol Reprod 93:69.

Leranth C, Hajszan T, MacLusky NJ (2004) Androgens increase spine synapse density in the CA1 hippocampal subfield of ovariectomized female rats. J Neurosci 24:495-499.

Livadas S, Pappas C, Karachalios A, Marinakis E, Tolia N, Drakou M, Kaldrymides P, Panidis D, Diamanti-Kandarakis E (2014) Prevalence and impact of hyperandrogenemia in 1,218 women with polycystic ovary syndrome. Endocrine 47:631-638.

McCartney CR, Eagleson CA, Marshall JC (2002) Regulation of gonadotropin secretion: implications for polycystic ovary syndrome. Semin Reprod Med 20:317-326.

McCartney CR, Blank SK, Prendergast KA, Chhabra S, Eagleson CA, Helm KD, Yoo R, Chang RJ, Foster CM, Caprio S, Marshall JC (2007) Obesity and sex steroid changes across puberty: evidence for marked hyperandrogenemia in pre- and early pubertal obese girls. J Clin Endocrinol Metab 92:430-436.

Moore AM, Prescott M, Marshall CJ, Yip SH, Campbell RE (2015) Enhancement of a robust arcuate GABAergic input to gonadotropin-releasing hormone neurons in a model of polycystic ovarian syndrome. Proc Natl Acad Sci USA 112:596-601.

Nunemaker CS, DeFazio RA, Moenter SM (2003) A targeted extracellular approach for recording long-term firing patterns of excitable cells: a practical guide. Biol Proced Online 5:53-62.

Padmanabhan V, Veiga-Lopez A (2013) Animal models of the polycystic ovary syndrome phenotype. Steroids 78:734-740.

Roland AV, Moenter SM (2011) Prenatal androgenization of female mice programs an increase in firing activity of gonadotropin-releasing hormone $(\mathrm{GnRH})$ neurons that is reversed by metformin treatment in adulthood. Endocrinology 152:618-628.

Roland AV, Nunemaker CS, Keller SR, Moenter SM (2010) Prenatal androgen exposure programs metabolic dysfunction in female mice. J Endocrinol 207:213-223.

Saloman JL, Scheff NN, Snyder LM, Ross SE, Davis BM, Gold MS (2016) Gi-DREADD expression in peripheral nerves produces 
ligand-dependent analgesia, as well as ligand-independent functional changes in sensory neurons. J Neurosci 36:10769-10781.

Sidman RL, Angevine JB, Pierce ET (1971) Atlas of the mouse brain and spinal cord. Cambridge: Harvard University Press.

Silva MSB, Desroziers E, Hessler S, Prescott M, Coyle C, Herbison AE, Campbell RE (2019) Activation of arcuate nucleus GABA neurons promotes luteinizing hormone secretion and reproductive dysfunction: implications for polycystic ovary syndrome. EBioMedicine 44:582-596.

Skynner MJ, Slater R, Sim JA, Allen ND, Herbison AE (1999) Promoter transgenics reveal multiple gonadotropin-releasing hormone-l-expressing cell populations of different embryological origin in mouse brain. J Neurosci 19:5955-5966.

Smith JT, Dungan HM, Stoll EA, Gottsch ML, Braun RE, Eacker SM, Clifton DK, Steiner RA (2005) Differential regulation of KiSS-1 mRNA expression by sex steroids in the brain of the male mouse. Endocrinology 146:2976-2984.

Soto F, Ma X, Cecil JL, Vo BQ, Culican SM, Kerschensteiner D (2012) Spontaneous activity promotes synapse formation in a cell-typedependent manner in the developing retina. J Neurosci 32:54265439.

Steyn FJ, Wan Y, Clarkson J, Veldhuis JD, Herbison AE, Chen C (2013) Development of a methodology for and assessment of pulsatile luteinizing hormone secretion in juvenile and adult male mice. Endocrinology 154:4939-4945.

Sullivan SD, Moenter SM (2004) Prenatal androgens alter GABAergic drive to gonadotropin-releasing hormone neurons: implications for a common fertility disorder. Proc Natl Acad Sci USA 101:71297134.
Suter KJ, Wuarin JP, Smith BN, Dudek FE, Moenter SM (2000) Whole-cell recordings from preoptic/hypothalamic slices reveal burst firing in gonadotropin-releasing hormone neurons identified with green fluorescent protein in transgenic mice. Endocrinology 141:3731-3736.

Tata B, Mimouni NE, Barbotin AL, Malone SA, Loyens A, Pigny P, Dewailly D, Catteau-Jonard S, Sundström-Poromaa I, Piltonen TT, Dal Bello F, Medana C, Prevot V, Clasadonte J, Giacobini P (2018) Elevated prenatal anti-Müllerian hormone reprograms the fetus and induces polycystic ovary syndrome in adulthood. Nat Med 24:834-846.

Thoma ME, McLain AC, Louis JF, King RB, Trumble AC, Sundaram R, Buck Louis GM (2013) Prevalence of infertility in the United States as estimated by the current duration approach and a traditional constructed approach. Fertil Steril 99:1324-1331.e1.

Vanacker C, Moya MR, DeFazio RA, Johnson ML, Moenter SM (2017) Long-term recordings of arcuate nucleus kisspeptin neurons reveal patterned activity that is modulated by gonadal steroids in male mice. Endocrinology 158:3553-3564.

Veldhuis JD, Johnson ML (1986) Cluster analysis: a simple, versatile, and robust algorithm for endocrine pulse detection. Am J Physiol 250:E486-E493.

Weinhard L, Neniskyte U, Vadisiute A, di Bartolomei G, Aygün N, Riviere L, Zonfrillo F, Dymecki S, Gross C (2018) Sexual dimorphism of microglia and synapses during mouse postnatal development. Dev Neurobiol 78:618-626.

Yoon H, Enquist LW, Dulac C (2005) Olfactory inputs to hypothalamic neurons controlling reproduction and fertility. Cell 123:669682. 